DOI: $10.21802 / \operatorname{artm} .2020 .1 .13 .140$.

УДК 616.24-006.6-089.168-085.825

\title{
ФІЗИЧНА ТЕРАПІЯ В ПІСЛЯОПЕРАЦІЙНОМУ ПЕРІОДІ У ХВОРИХ НА РАК ЛЕГЕНІ
}

\author{
А.І. Шевченко ${ }^{1}$, С.Л. Михалюк ${ }^{2}$, С.М. Малахова ${ }^{2}$, С.Г. Пузік ${ }^{2}$, Л.І. Левченко ${ }^{2}$ \\ Запорізький державний медичний університет, \\ ${ }^{1}$ кафедра онкології та онкохірургії, \\ ${ }^{2}$ кафедра фізичної реабілітації, спортивної медицини, фізичного виховання $i$ здоров'я, \\ м. Запоріжжя, Украӥна, \\ ORCID ID: 0000-0001-8553-1203, ORCID ID: 0000-0003-3607-7619, \\ ORCID ID: 0000-0002-1041-2397, ORCID ID: 0000-0003-3747-2389, \\ ORCID ID: 0000-0003-2897-263X, \\ e-mail: shevchenkoai.49@gmail.com
}

Резюме. Рак легені продовжує посідати перше місце в структурі онкозахворюваності чоловіків, постійно зростає кількість хворих працездатного віку після радикального лікування. на рак легені.

Мета роботи - дослідити вплив фізичної терапії на стан зовнішнього дихання у прооперованих хворих

Матеріали і методи. Вивчення впливу фізичної терапії на стан зовнішнього дихання проведене у 332 хворих після лоб- та білобектомій через рік після операції. 156 пацієнтів, які з тих чи інших причин відмовилися від виконання фізичних вправ за програмою фізичної терапії, входили до контрольної групи. В основній групі, що складалася 3176 пацієнтів, був проведений повноцінний курс фізичної терапії в найближчому і відстроченому періодах після операції. Контроль стану зовнішнього дихання проводили за допомогою спірографії, а стан працевлаштування - шляхом опитування хворих.

Результати дослідження. Більшість показників спірографії при застосуванні фізичних вправ достовірно перевищували аналогічні дані у хворих контрольної групи. Відсоток хворих, які повернулися до праці, у досліджуваній групі є достовірно більшим, ніж у контрольній. Спостерігалось також і зменшення інвалідизації хворих у досліджуваній групі.

Висновки. Встановлено, що використання фізичної терапії в післяопераційному періоду у хворих на рак легені суттєво поліпшує відновлення дихальної функції і полегшує повернення до побутових і професійних навантажень. Критеріями для призначення програми занять з фізичної терапії повинні бути вік, стать, загальний стан здоров'я пацієнта та результати початкового реабілітаційного обстеження, а також індивідуальна реакція на фізичні навантаження. Для стимуляції участі пацієнтів у процесі відновлення рекомендується покращити сприйнятий поведінковий контроль (самореалізацію) пацієнта стосовно методів фізичної терапії.

Ключові слова: рак легені, післяопераційний період, фізична терапія.

Вступ. Серед 38 завдань розробленої ВОО3 Європейської стратегії досягання здоров'я для всіх людей друге місце посіло завдання, яке отримало назву «додати життя до років». Зміст цього завдання розкривався таким чином: «...всім людям повинна бути забезпечена можливість розвитку і використання їх власного потенціалу здоров'я для того, щоб вести повноцінне в соціальному, економічному і духовному плані життя». Тобто здоров'я визначається як стан повного фізичного, психічного і соціального благополуччя, а не тільки відсутність хвороб та інвалідності.

Як у всьому світі, так і в Україні вже тривалий час спостерігається негативна тенденція до щорічного зростання захворюваності на рак легені. У структурі онкологічної захворюваності чоловічого населення України ця онкопатологія стійко утримує перше місце $[4,8]$. Практично єдиним методом радикального лікування раку легень залишаються радикальні хірургічні операції, зокрема лоб- і білобектомія та пульмонектомія [2, 5, 7], отже, кількість пацієнтів, прооперованих 3 приводу раку легень, постійно зростає.

Обгрунтування дослідження. Зважаючи на те, що спеціально розроблені фізичні вправи мають позитивний вплив на функціональний стан апарату зовнішнього дихання $[1,3,6,9-13]$, необхідність їх застосування як у комплексній підготовці хворих на рак легені до торакальних операцій, так і в період післяопераційної фізичної терапії є беззаперечною.

Перш ніж розпочати аналіз впливу реабілітаційних заходів на подальшу долю хворих, слід зробити наголос на тому, що фізичну терапію більш доцільно зв'язувати з розвитком, ніж з адаптацією. Поняття розвитку передбачає активність і зміну. Розвиток - це більш відкрита категорія, ніж адаптація; розвиток - це більше, ніж ріст. У цьому сенсі про реабілітацію можливо говорити як про тренінг розвитку. Коли ж ми ведемо мову про заходи, спрямовані на поліпшення функції зовнішнього дихання, серцево-судинної системи, тощо, то передбачаємо при цьому досягнення таких критеріїв або показ- 
ників, які б дозволили хворому адаптуватися до певних умов праці. Тим самим ми виконуємо цілі суспільства, медицини, спрямовані на збереження здоров'я і працездатності людей. Але при цьому за "деревами" проблем майже ніколи не помічається "ліс"; головна ціль - ціль того, хто відновлюється. Вона є головною тому, що інтеріоризована ціль діяльності як внутрішній образ керує процесом фізичної терапії. Тобто зовнішні впливи, причини, подразники, реабілітаційні заходи можуть вплинути на людину тільки через внутрішні умови. Широко інтерпретуючи ці внутрішні умови, можна сказати, що це $є$ особистість і життєвий шлях людини. Ніякі заходи щодо фізичної терапії не можуть дати будь-якого постійного, незмінного результату. Вони завжди залежать від особистості кожної особи, що відновлюється. Активність самого суб'єкту - це ключ до всіх змін. Саме тому на одне 3 перших місць у комплексі заходів фізичної терапії ми поставили психологічну роботу. Якщо на передопераційному етапі вона була спрямована на подолання страху, тривожності, то після операції вона спрямовувалась на формування мотиву відновлення, надбання сенсу життя. Адже людина не тільки опановує себе і навколишнє середовище, не тільки адаптується до умов життя, але й сама створює своє середовище і процес реабілітації.

Отже, головною метою фізичної терапії повинно бути те, щоб вона починалася для хворого урочистим і добре знайомим словом «ХОЧУ». І лише після цього «ХОЧУ» повинно зіставлятися 3 «ТРЕБА» $\mathrm{i} \ll \mathrm{МОЖУ».}$

Мета роботи: дослідити вплив фізичної терапії на стан зовнішнього дихання у прооперованих хворих на рак легені.

Матеріали і методи. До досліджуваної групи увійшли 356 хворих, виписаних із торакального відділення Запорізького обласного клінічного онкологічного диспансеру після хірургічного і комбінованого лікування. Контрольну групу склали 386 хворих, виписаних після хірургічних методів лікування. Групи хворих були співставними за показниками віку, наявністю супутніх захворювань.

Через рік після операції вплив фізичної реабілітації на стан зовнішнього дихання вивчений у

332 хворих після лоб- та білобектомій. 3 них 156 входили до контрольної групи, які з тих або інших причин відмовились від виконання лікувальної гімнастики. 3 досліджуваної групи обстежено 176 хворих. Їм проведений повноцінний курс фізичної терапії у найближчому і відтермінованому періодах після операції.

Значним кроком у відновленні хворих на рак легені стала співпраця в цьому напрямку із кафедрою фізичної реабілітації, спортивної медицини, фізичного виховання i здоров'я Запорізького державного медичного університету. Онкохворі отримали можливість відновлювати стан свого здоров'я після радикального лікування на цій базі під керівництвом досвідчених фахівців.

Відбір хворих на фізичну терапію відбувався виключно індивідуально з урахуванням їх бажання, протипоказань і певних обмежень. На цей етап лікування скеровувались виключно хворі 3 третьою клінічною групою диспансерного обліку. Метою фізичної терапії було попередження ускладнень від проведеного радикального протипухлинного лікування, а саме: легенева недостатність та недостатність кровообігу I ст., обмеження рухів у плечовому суглобі, викривлення хребта та підготовка хворих до побутових навантажень. Для цього проводились комплекси лікувальних вправ, скерованих на тренування серцево-судинної і дихальної систем, відновлення повного об'єму рухів у плечовому суглобі на боці операції, попередження деформації грудної клітки i хребта, укріплення всіх м'язів, збільшення рухомості грудної клітки та діафрагми.

3 перспективами і методами фізичної терапії знайомили не тільки самого хворого, але й членів його родини. Таким чином формували активну i відповідальну позицію хворого і його родичів щодо відновлюваного лікування і його продовження в домашніх умовах.

Контроль стану зовнішнього дихання проводили за допомогою спірографії, а стан працевлаштування - шляхом опитування хворих.

Результати досліджень та їх обговорення. У таблиці 1 наведені спірографічні показники через рік після операції.

Таблиця 1

Показники легеневої вентиляції і бронхіальної прохідності у хворих на рак легені через рік після лоб- та білобектомій залежно від застосування лікувальних фізичних вправ

\begin{tabular}{|c|c|c|c|}
\hline Спірографічні & \multicolumn{2}{|c|}{ Групи оперованих хворих та їх кількість } & Р \\
\hline показники & $\begin{array}{c}\text { Без проведення фізичних } \\
\text { вправ (156 чол.) }\end{array}$ & $\begin{array}{c}\text { 3 проведенням лікувальної } \\
\text { гімнастики (176 чол.) }\end{array}$ & $<0,05$ \\
\hline ЧД на хв. & $20,3 \pm 0,9$ & $17,6 \pm 0,5$ & $<0,05$ \\
\hline ДО, мл & $437,0 \pm 30,5$ & $596,4 \pm 23,4$ & $>0,05$ \\
\hline ХОД, мл & $8869,0 \pm 852,0$ & $10350,3 \pm 270,5$ & $<0,05$ \\
\hline МВЛ, л & $47,3 \pm 5,4$ & $60,2 \pm 2,5$ & $>0,05$ \\
\hline ЖЄЛ, мл & $2205,6 \pm 147,3$ & $2386,5 \pm 102,0$ & $>0,05$ \\
\hline ЖСЛ/НЄЛ, \% & $81,6 \pm 2,6$ & $84,3 \pm 3,2$ & $<0,05$ \\
\hline ФЖСЛ мЛ & $1510,0 \pm 108,0$ & $1843,7 \pm 119,2$ & $<0,05$ \\
\hline ФЖСЛ/ЖЄЛ, \% & $68,5 \pm 1,4$ & $74,3 \pm 2,2$ & \\
\hline
\end{tabular}

Як видно з наведених даних, більшість показників спірографії при застосуванні фізичних вправ достовірно перевищували аналогічні дані у хворих контрольної групи. Крім числових показників 
зовнішнього дихання, аналізувався також тип кривої "потік-об'єм" у цих групах.

Якщо у контрольній групі, де лікувальна гімнастика не застосовувалась, крива форсованого видиху свідчила про наявність порушень прохідності бронхів середнього і мілкого калібру, то в групі хвоpих iз застосуванням фізичних вправ порушень прохідності бронхів малого калібру було значно меншим і крива видиху за своєю формою була близькою до норми.
Одним 3 важливих факторів, що в тій або іншій мірі визначають соціально-трудову активність хворих після радикального лікування раку легені, $\epsilon$ визначення їм групи інвалідності. Із 225 хворих на рак легені через рік після радикального лікування I група інвалідності визначена у 6 (2,7\%), II група - у $23(10,2 \%)$, III група - у 90 (40,0 \%), визнано працездатними 106 хворих (47,1\%) (табл. 2).

Стан працездатності радикально оперованих хворих на рак легені через рік після операції

\begin{tabular}{|c|c|c|c|c|c|c|c|}
\hline \multirow[t]{2}{*}{$\begin{array}{c}\text { Групи } \\
\text { обстежених }\end{array}$} & \multirow[t]{2}{*}{$\begin{array}{l}\text { Характер } \\
\text { операції }\end{array}$} & \multirow[t]{2}{*}{$\begin{array}{c}\text { Кіль- } \\
\text { кість } \\
\text { хворих } \\
\end{array}$} & \multicolumn{2}{|c|}{$\begin{array}{c}\text { Повернулися до роботи в } \\
\text { термін }\end{array}$} & \multicolumn{3}{|c|}{ Визнані інвалідами } \\
\hline & & & до 1 року & після 1 року & I групи & II групи & III групи \\
\hline \multirow[t]{4}{*}{$\begin{array}{l}\text { Досліджува } \\
\text { на }\end{array}$} & $\begin{array}{l}\text { Лоб- та } \\
\text { білобектомі } \\
\ddot{i}\end{array}$ & 170 & $\begin{array}{c}78 \\
45,9 \pm 3,8 \\
\% \\
\mathrm{P}<0,001\end{array}$ & $\begin{array}{c}13 \\
7,6 \pm 2,0 \% \\
\mathrm{P}<0,05\end{array}$ & - & $\begin{array}{c}8 \\
4,7 \pm 1,6 \% \\
P>0,05\end{array}$ & $\begin{array}{c}71 \\
41,8 \pm 3,8 \% \\
\mathrm{P}<0,05\end{array}$ \\
\hline & $\begin{array}{l}\text { пульмон- } \\
\text { ектомії }\end{array}$ & 55 & - & $\begin{array}{c}15 \\
27,3 \pm 6,1 \% \\
\mathrm{P}>0,05 \\
\end{array}$ & $\begin{array}{c}6 \\
10,9 \pm 4,2 \% \\
P>0,05\end{array}$ & $\begin{array}{c}15 \\
27,3 \pm 6,1 \% \\
\mathrm{P}<0,05\end{array}$ & $\begin{array}{c}19 \\
34,5 \pm 6,5 \% \\
\mathrm{P}<0,05\end{array}$ \\
\hline & Разом: & 225 & \multicolumn{2}{|c|}{$106(47,1 \pm 3,3 \%) \mathrm{P}<0,001$} & \multicolumn{3}{|c|}{$119(52,9 \pm 3,3 \%) \mathrm{P}<0,001$} \\
\hline & $\begin{array}{l}\text { Лоб- та } \\
\text { білобектомі } \\
\text { ї }\end{array}$ & 193 & $\begin{array}{c}43 \\
22,3 \pm 3,0 \\
\%\end{array}$ & $\begin{array}{c}30 \\
15,5 \pm 2,6 \%\end{array}$ & - & $\begin{array}{c}19 \\
9,9 \pm 2,1 \%\end{array}$ & $\begin{array}{c}101 \\
52,3 \pm 3,6 \%\end{array}$ \\
\hline \multirow[t]{2}{*}{ Контрольна } & $\begin{array}{l}\text { пульмон- } \\
\text { ектомії }\end{array}$ & 98 & - & $\begin{array}{c}20 \\
20,4 \pm 4,1 \%\end{array}$ & $\begin{array}{c}18 \\
18,4 \pm 3,9 \%\end{array}$ & $\begin{array}{c}45 \\
45,9 \pm 5,1 \%\end{array}$ & $\begin{array}{c}15 \\
15,3 \pm 3,6 \%\end{array}$ \\
\hline & Разом: & 291 & \multicolumn{2}{|c|}{$93(31,9 \pm 2,7 \%)$} & \multicolumn{3}{|c|}{$198(68,0 \pm 2,7 \%)$} \\
\hline
\end{tabular}

Примітка: $\mathrm{p}$ - у порівнянні з контрольною групою

Обмеження працездатності у хворих з I групою інвалідності було обумовлено наявністю значно виражених клінічних проявів порушення функції дихання (ДН III ступеня, декомпенсоване легеневе серце, недостатність кровообігу III стадії), інструментальних ознак порушень функції дихання і кровообігу (рентгенологічні дані про масивні плевральні нашарування, парез куполу діафрагми, різке зміщення середостіння в бік оперованої легені; відповідні дані спірографічного дослідження і аналізу кривих потікоб'єм; електрокардіографічні дані про наявність різкого зниження скоротливої здібності міокарду, порушень серцевого ритму, гіпоксії міокарду).

У хворих з ІІ групою інвалідності обмеження працездатності було обумовлено наявністю виражених клінічних проявів порушення функції дихання (ДН II ступеня, хронічне легеневе серце, компенсоване або субкомпенсоване; недостатність кровообігу I-II стадії); виражених клініко-інструментальних ознак порушень функції дихання (значні порушення функції зовнішнього дихання при спірографічному обстеженні, значні рентгенологічні зміни - грубі плевральні зрощення, обмеження рухомості діафрагми); електрокардіографічні дані, які свідчать про зниження скоротливої здібності міокарду, порушення коронарного кровотоку.

Хворі з III групою інвалідності мали помірні клінічні прояви та інструментальні ознаки порушень функції зовнішнього дихання - ДН 0-І ступеня, від- сутність ознак легеневого серця, рентгенологічно визначались невеликі плевральні нашарування.

Вивчення фактичного працевлаштування пролікованих хворих показало, що з 36 пацієнтів з II групою інвалідності працювали на дому і на роботах, які не пов'язані 3 фізичним навантаженням, 11 (30,5\%). 387 хворих із III групою працювали після раціонального працевлаштування 75 чоловік (86,2 \%). Таким чином, до суспільно корисної праці було залучено 192 пацієнти $(85,3 \%)$.

Одним 3 критеріїв, що наочно характеризують вплив фізичної терапії, $є$ термін відновлення соціально-трудової активності і повернення хворих до систематичної трудової діяльності. За нашими даними, з 170 хворих досліджуваної групи, які перенесли лоб- або білобектомію, 78 пацієнтів відновили трудову діяльність у перші шість місяців після операції. Це, в основному, були хворі з локалізованими формами пухлин (Т1-2 N0 M0). Слід підкреслити, що 263 них (33,3 \%) були визнані працездатними ЛКК ЛПЗ без направлення на МСЕК, 13 були продовжені терміни тимчасової непрацездатності, і потім вони почали свою трудову діяльність. При вирішенні питання про відновлення трудової діяльності обов'язково аналізувались умови, в яких буде працювати пацієнт, характер професійних і соціально-психологічних навантажень на виробництві.

Таким чином, 3 тих хворих після лобектомії, що повернулися до праці, значна частина була визнана працездатними або обмежено працездатними у 
перші 6-8 міс. після операції. Цьому значною мірою сприяло також і більш швидке та повноцінне відновлення функції зовнішнього дихання у хворих досліджуваної групи завдяки застосуванню фізичної терапії.

3 таблиці 2, в якій наведені порівняльні дані щодо відновлення працездатності у хворих контрольної та досліджуваної груп, видно, що відсоток хворих, які повернулися до праці, у досліджуваній групі $\epsilon$ достовірно більшим, ніж у контрольній, відповідно $47,1 \pm 3,3$ i $31,9 \pm 2,7 \%(\mathrm{P}<0,001)$. Ця різниця у хворих після часткових резекцій легені спостерігається вже протягом першого року після операції. Так, до роботи в досліджуваній групі повернулися в термін до 1-го року $78(45,9 \pm 3,8 \%)$ хворих, а в контрольній -43 $(22,3 \pm 3,0 \%)(\mathrm{P}<0,001)$.

Спостерігалось також і зменшення інвалідизації хворих у досліджуваній групі. Так, інвалідами в

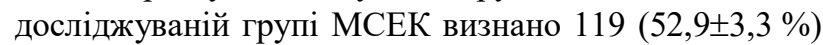
хворих, а в контрольній $-198(68,0 \pm 2,7$ \%) $(\mathrm{P}<0,001)$.

Суттєвої зміни положення щодо підвищення працездатності в групі хворих після пульмонектомії досягти не вдалося із очевидних причин - у цій групі хворих неможливо було застосувати запропоновані нами методи поліпшення зовнішнього дихання.

Цікаво було простежити процес відновлення працездатності в залежності від відношення пацієнтів до тієї чи іншої професійної групи. Найбільше повернення до активної трудової діяльності в перший рік спостерігалося серед осіб, що займалися розумовою та висококваліфікованою фізичною роботою - 31 з 47 хворих, що становить $65,9 \% .3$ даних опитування хворих можливо зробити цьому логічне пояснення. Більш висока свідомість хворих цієї групи сприяла більш ретельному додержанню рекомендацій лікаря перед випискою. Більшість пацієнтів у післяопераційному періоді виконували дихальні і фізичні вправи, кинули палити. Це в значній мірі сприяло подальшому розвитку компенсаторних процесів i нормалізації стану хворих. Це також наочно ілюструє вплив вищезгаданого "ХОЧУ" на подальший перебіг хвороби і процес відновлення. Крім цього розумова та висококваліфікована фізична праця потребувала значно меншого навантаження на дихальний апарат хворих. Серед осіб некваліфікованої фізичної праці до роботи повернулося 47 з 103 пацієнтів (45,6 \%). Це достовірно перевищує аналогічні показники контрольної групи, які, відповідно, дорівнювали 59,8 та $14,0 \%$.

Пацієнти, які працевлаштувалися протягом першого року після радикального лікування, як правило, повертались до праці у більш ранній термін, ніж ті, хто раніше не працював. Як свідчать дані опитування, абсолютна більшість пацієнтів, які бажають працевлаштуватися, реалізують своє бажання незалежно від висновку МСЕК.

\section{Висновки:}

Використання фізичної терапії в післяопераційному періоді у хворих на рак легені суттєво поліпшує відновлення дихальної функції і полегшує повернення на роботу.
Критеріями для призначення занять 3 фізичної терапії повинні бути вік, стать, загальний стан здоров'я пацієнта та результати початкового реабілітаційного обстеження, а також індивідуальна реакція на фізичні навантаження, яка визначається за допомогою ЕКГ та спірографії.

Для стимуляції участі пацієнтів у процесі відновлення рекомендується покращити сприйнятий поведінковий контроль (самореалізацію) пацієнта стосовно методів фізичної терапії.

\section{References:}

1. Dimova OV, Evdokimov EI. Application exercises for rehabilitation of patients with lung cancer after surgical treatment. Problems of physical education and sports. 2010; 6:59-62.

2. Kolesnik OP. Efficiency of surgical treatment of patients with stage I-II non-small cell lung cancer / Current issues of modern medicine: Bulletin of the Ukrainian Medical Dental Academy. 2013; 13, 4(44):27-31.

3. Program for rehabilitation of cancer patients. Available from:https://oncorehab.online /info?fbclid=Iw AR1PNZdEQKWm8H3W3PzqLPeiHwg3V9y_KdHf fWQY-OUldtKzEKT7XBWiNU0

4. Cancer in Ukraine, 2017-2018. Bulletin of the National Cancer Register of Ukraine № 20. Kolesnik OP, Kiev. 2019.

5. Lung cancer. Adapted clinical guideline based on evidence. Ganul VL, Ganul AV, Shevchenko AI, Kolesnik OP, Kiev. 2015. Available from: file://C:/Users/1/Downloads/2014_387\%20AKN\%20 RakLegeni.pdf

6. Timruk-Skoropad KA. Physical rehabilitation of patients with radical treatment of lung cancer in hospital: Method. tool. for rehabilitologists ed. OI Ryabukha. L., 2005. P.48.

7. Ustinov OV. Highly specialized medical care for lung cancer. Ukrainian Medical Journal. 2016. Available from: https://www.umj.com.ua /article/95660/ visokospecializovana-medichna-dopomoga-pri-rakulegeni

8. Bray F, Ferlay J, Soerjomataram I, Siegel RL, Torre LA, Jemal A. Global cancer statistics 2018: GLOBOCAN estimates of incidence and mortality world wide for 36 cancersin 185 countries. CA Cancer J Clin. 2018; 68(6):394-424.

9. Coats V, Maltais F, Tremblay L, Saey D. ExerciseBased Rehabilitation for People with Lung Cancer. J Pulm Respir Med. 2014; 4:183. Available from: https://www.omicsonline.org/openaccess/exercisebased-rehabilitation-for-people-withlung-cancer-2161-105X.1000183.php?aid=25530

10. Granger C, McDonald C, Irving L, Clark R, Gough K, Murnane A, et al. Low physical activity level sand functional declinein individuals with lung cancer. LungCancer. 2014; 83:292-299.

11. Granger CL. Physio therapy management of lung cancer. Journal of Physio therapy. 2016; 62:60-67.

12. Jones LW, Eves ND, Kraus WE, Potti A, Crawford J, et al. The lung cancer exercise training study: a randomized trial of aerobic training, resistance 
training, or both in postsurgical lung cancer patients: rationale and design. BMC cancer10:155. LungCancer. 2014; 83:292-299.

13. Shannon VR. Role of pulmonary rehabilitation in the management of patients with lung cancer. Curr Opin Pulm Med. 2010; 16(4):334-339.

\section{УДК 616.24-006.6-089.168-085.825}

\section{ФИЗИЧЕСКАЯ ТЕРАПИЯ В ПОСЛЕОПЕРАЦИ- ОННОМ ПЕРИОДЕ У БОЛЬНЫХ РАКОМ ЛЕГКОГО}

\author{
А.И. Шевченко ${ }^{1}$, Е.Л. Михалюк ${ }^{2}$ С.Н. Малахова ${ }^{2}$, \\ С.Г. Пузик ${ }^{2}$, Л.И. Левченко ${ }^{2}$
}

\section{Запорожский государственный медицинский} университет

${ }^{1}$ кафедра онкологии и онкохирургии,

${ }^{2}$ кафедра физической реабилитации, спортивной медицины, физического воспитания и здоров'я,

2. Запорожье, Украина,

ORCID ID: 0000-0001-8553-1203,

ORCID ID: 0000-0003-3607-7619,

ORCID ID: 0000-0002-1041-2397,

ORCID ID: 0000-0003-3747-2389,

ORCID ID: 0000-0003-2897-263X,

e-mail: shevchenkoai.49@gmail.com

Резюме. Рак легкого продолжает занимать первое место в структуре онкозаболеваемости мужчин, постоянно растет количество больных трудоспособного возраста после радикального лечения.

Цель работы - определить влияние физической терапии на состояние внешнего дыхания у прооперированных больных раком легкого.

Материалы и методы. Изучение влияния физической терапии на состояние внешнего дыхания проведено у 332 больных после лоб- и билобектомий через год после операции. 156 пациентов, которые по тем или иным причинам отказались от выполнения физических упражнений по программе физической терапии, входили в контрольную группу. В основной группе, состоящей из 176 пациентов, был проведен полноценный курс физической терапии в ближайшем и отсроченном периодах после операции. Контроль состояния внешнего дыхания проводили с помощью спирографии, а состояние трудоустройства - путем опроса больных.

Результаты исследования. Большинство показателей спирографии при применении физических упражнений достоверно превышали аналогичные данные у больных контрольной группы. Процент пациентов, вернувшихся к труду, в исследуемой группе достоверно выше, чем в контрольной. Наблюдалось также и уменьшение инвалидизации больных в исследуемой группе.

Выводы. Установлено, что использование физической терапии в послеоперационном периоде у больных раком легкого существенно улучшает восстановление дыхательной функции и облегчает возвращение к бытовым и профессиональным нагруз- кам. Установлено, что критериями для назначения программы занятий по физической терапии должны быть возраст, пол, общее состояние здоровья пациента и результаты начального реабилитационного обследования, а также индивидуальная реакция на физические нагрузки. Для стимуляции участия пациентов в процессе восстановления, рекомендуется улучшить поведенческий контроль (самореализацию) пациента относительно методов физической терапии.

Ключевые слова: рак легкого, послеоперационный период, физическая терапия.

\section{UDC 616.24-006.6-089.168-085.825 \\ PHYSICAL THERAPY DURING POSTOPERA- TIVE PERIOD IN PATIENTS WITH LUNG CANCER}

A.I. Shevchenko ${ }^{1}$, E.L. Mikhalyuk ${ }^{2}$, S.N. Malakhova ${ }^{2}$, S.G. Puzik ${ }^{2}$, L.I. Levchenko ${ }^{2}$

Zaporizhzhya State Medical University,

${ }^{I}$ Department of Oncology and Oncosurgery,

${ }^{2}$ Department of Physical Rehabilitation, Sports Medicine, Physical Training and Health,

Zaporizhzhya, Ukraine,

ORCID ID: 0000-0001-8553-1203,

ORCID ID: 0000-0003-3607-7619,

ORCID ID: 0000-0002-1041-2397,

ORCID ID: 0000-0003-3747-2389,

ORCID ID: 0000-0003-2897-263X,

e-mail: shevchenkoai.49@gmail.com

Abstract. WHO have developed an average of 38 tasks for a European strategy that has received health for all people who have been referred to as "lifelong life". The content of this task was revealed as follows: "... all people should be given the opportunity to develop and use their own health potential in order to lead a full social, economic and spiritual life. That is, health is defined as a state of complete physical, mental and social wellbeing, not just the absence of illness and disability.

Lung cancer continues to occupy the first place in the structure of male oncological morbidity. The number of working age patients after radical treatment is constantly growing.

The aim of the study was to investigate the effect of physical therapy on the state of external respiration in operated lung cancer patients.

Materials and methods. Effect of physical therapy on external respiration was studied in 332 patients with lung cancer after one year after surgery. Of these, 156 patients, who for various reasons refused to perform therapeutic exercises, were included in the control group. In the main group, in the immediate and delayed periods after surgery, 176 patients with a full course of physical therapy were examined. External breathing was monitored by Spirograph and employment status by interviewing patients.

Considering that there are complications from radical antitumor treatment in the form of pulmonary and 
circulatory insufficiency of degree I, restriction of movements in the shoulder joint, curvature of the spine we performed complexes of medical exercises. It aimed at training of cardiovascular and respiratory systems in the shoulder joint on the side of surgery, prevention of deformation of the chest and spine, strengthening of all muscles, increase of mobility of the chest and diaphragm, and preparation of min. nut to household loads.

Results. Most indicators of Spirograph when using exercise significantly exceeded the same data in patients in the control group. The percentage of patients returning to work in the study group is significantly higher than in the control group. There was also a decrease in the disability of patients in the study group. Patients, who were employed during the first year after radical treatment, generally returned to work earlier than those who had not previously worked. According to the survey data, the vast majority of patients wishing to find a job fulfill their desire regardless of the opinion of the medical board.
Significant changes in the situation regarding the increase of working capacity in the group of patients after pulmonectomy could not be achieved for obvious reasons - in this group of patients, it was impossible to apply our proposed methods of improving external respiration.

Conclusions. Thus, the use of physical therapy in the postoperative period in patients with lung cancer significantly improves the restoration of respiratory function and facilitates the return to work. It was established that the criteria for the appointment of a program for withdrawal from physical therapy should be the age, gender, general health of the patient and the results of the initial rehabilitation examination, as well as the individual response to physical exertion. In order to stimulate patients' participation in rehabilitation, it is recommended to improve the patient's perceived behavioral control of physical therapy methods.

Keywords: lung cancer, postoperative period, physical therapy.

Стаття надійшла в редакцію 16.12.2019 р. 